\title{
Front Matter: Volume 9116
}

, "Front Matter: Volume 9116," Proc. SPIE 9116, Next-Generation Robots and Systems, 911601 (23 June 2014); doi: 10.1117/12.2072970

SPIE Event: SPIE Sensing Technology + Applications, 2014, Baltimore, MD, United SPIE. States 


\section{PROCEEDINGS OF SPIE}

\section{Next-Generation Robots and Systems}

Dan O. Popa

Muthu B. J. Wijesundara

Editors

8 May 2014

Baltimore, Maryland, United States

Sponsored and Published by

SPIE 
The papers included in this volume were part of the technical conference cited on the cover and title page. Papers were selected and subject to review by the editors and conference program committee. Some conference presentations may not be available for publication. The papers published in these proceedings reflect the work and thoughts of the authors and are published herein as submitted. The publisher is not responsible for the validity of the information or for any outcomes resulting from reliance thereon.

Please use the following format to cite material from this book:

Author(s), "Title of Paper," in Next-Generation Robots and Systems, edited by Dan O. Popa, Muthu B. J. Wijesundara, Proceedings of SPIE Vol. 9116 (SPIE, Bellingham, WA, 2014) Article CID Number.

ISSN: 0277-786X

ISBN: 9781628410532

Published by

SPIE

P.O. Box 10, Bellingham, Washington 98227-0010 USA

Telephone +1 3606763290 (Pacific Time) · Fax +1 3606471445

SPIE.org

Copyright (c) 2014, Society of Photo-Optical Instrumentation Engineers.

Copying of material in this book for internal or personal use, or for the internal or personal use of specific clients, beyond the fair use provisions granted by the U.S. Copyright Law is authorized by SPIE subject to payment of copying fees. The Transactional Reporting Service base fee for this volume is $\$ 18.00$ per article (or portion thereof), which should be paid directly to the Copyright Clearance Center (CCC), 222 Rosewood Drive, Danvers, MA 01923. Payment may also be made electronically through CCC Online at copyright.com. Other copying for republication, resale, advertising or promotion, or any form of systematic or multiple reproduction of any material in this book is prohibited except with permission in writing from the publisher. The CCC fee code is 0277-786X/14/\$18.00.

Printed in the United States of America.

Publication of record for individual papers is online in the SPIE Digital Library.

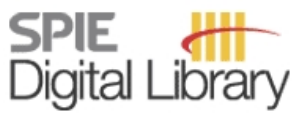

SPIEDigitalLibrary.org

Paper Numbering: Proceedings of SPIE follow an e-First publication model, with papers published first online and then in print and on CD-ROM. Papers are published as they are submitted and meet publication criteria. A unique, consistent, permanent citation identifier (CID) number is assigned to each article at the time of the first publication. Utilization of CIDs allows articles to be fully citable as soon as they are published online, and connects the same identifier to all online, print, and electronic versions of the publication. SPIE uses a six-digit CID article numbering system in which:

- The first four digits correspond to the SPIE volume number.

- The last two digits indicate publication order within the volume using a Base 36 numbering

system employing both numerals and letters. These two-number sets start with 00, 01, 02, 03, 04, $05,06,07,08,09,0 A, 0 B \ldots$. 0Z, followed by 10-1Z, 20-2Z, etc.

The CID Number appears on each page of the manuscript. The complete citation is used on the first page, and an abbreviated version on subsequent pages. Numbers in the index correspond to the last two digits of the six-digit CID Number. 


\title{
Contents
}

\author{
$\checkmark \quad$ Conference Committee \\ vii Introduction
}

\section{SESSION 1 SENSORS FOR NEXT-GENERATION ROBOTICS I}

911602 A haptic sensing upgrade for the current EOD robotic fleet (Invited Paper) [91 16-1] P. Rowe, RE², Inc. (United States)

911603 Tactile MEMS-based sensor for delicate microsurgery [9116-2]

Y. S. Park, Argonne National Lab. (United States); W. Lee, The Univ. of Texas at Arlington (United States); N. Gopalsami, Argonne National Lab. (United States); M. Gundeti, The Univ. of Chicago Medical Ctr. (United States)

911604 Tactile sensing and compliance in MicroStressBot assemblies [91 16-3]

R. Majumdar, V. Foroutan, I. Paprotny, Univ. of Illinois at Chicago (United States)

911605 Haptic exploration of fingertip-sized geometric features using a multimodal tactile sensor [91 16-4]

R. D. Ponce Wong, R. B. Hellman, V. J. Santos, Arizona State Univ. (United States)

\section{SESSION 2 SENSORS FOR NEXT-GENERATION ROBOTICS II}

911606 Experimental testbed for robot skin characterization and interaction control [91 16-5] K. R. Shook, A. Habib, W. H. Lee, D. O. Popa, The Univ. of Texas at Arlington (United States)

911607 Conformal grasping using feedback controlled bubble actuator array [9116-6] W. Carrigan, R. Stein, M. Mittal, M. B. J. Wijesundara, The Univ. of Texas at Arlington Research Institute (United States)

911608 Development and characterization of a new silicone/platine based 2-DoF sensorized end-effector for micromanipulators [9116-7]

X. Xu, J. Agnus, M. Rakotondrabe, FEMTO-ST Institute, CNRS, Univ. de Franche-Comté (France)

911609 A multidirectional capacitive proximity sensor array [9116-8]

J. Long, Mitsubishi Electric Research Labs. (United States) and Univ. of California, San Diego (United States); B. Wang, Mitsubishi Electric Research Labs. (United States)

\section{SESSION $3 \quad$ SENSORS FOR NEXT-GENERATION ROBOTICS III}

$91160 \mathrm{~A} \quad$ Needs and emerging trends of remote sensing [91 16-9]

M. McNair, The Univ. of Texas at Arlington (United States) 
$9116 \mathrm{OB}$ Toward controlling perturbations in robotic sensor networks [9116-10]

A. G. Banerjee, S. R. Majumder, General Electric Global Research (United States)

$91160 \mathrm{C}$ Advanced THz sensor array for precise position and material properties recognition [9116-11]

A. Sešek, J. Trontelj, Univ. of Ljubljana (Slovenia); A. Švigelj, Letrika Lab. d.o.o (Slovenia)

$91160 D$ Sensor selection for outdoor air quality monitoring [9116-12]

K. L. Dorsey, J. R. Herr, Univ. of California, Berkeley (United States); A. P. Pisano, Univ. of California, San Diego (United States)

\section{SESSION 4 SENSORS FOR NEXT-GENERATION ROBOTICS IV}

9116 OF EHD as sensor fabrication technology for robotic skins [9116-14]

J. Shin, W. H. Lee, C. P. Nothnagle, M. B. J. Wijesundara, The Univ. of Texas at Arlington Research Institute (United States)

$91160 \mathrm{H} \quad$ Grip pressure measurements during activities of daily life [9116-20]

J. Sanford, The Univ. of Texas at Arlington (United States); C. Young, Univ. of North Texas Health Science Ctr. at Fort Worth (United States); D. Popa, The Univ. of Texas at Arlington (United States); N. Bugnariu, R. Patterson, Univ. of North Texas Health Science Ctr. at Fort Worth (United States)

Author Index 


\title{
Conference Committee
}

\author{
Symposium Chair \\ David A. Whelan, Boeing Defense, Space, and Security \\ (United States) \\ Symposium Co-chair \\ Wolfgang Schade, Technische Universität Clausthal (Germany) and \\ Fraunhofer Heinrich-Hertz-Institut (Germany) \\ Conference Chairs \\ Dan O. Popa, The University of Texas at Arlington (United States) \\ Muthu B. J. Wijesundara, The University of Texas at Arlington Research \\ Institute (United States) \\ Conference Program Committee
}

Rakesh Murthy, Jet Propulsion Laboratory (United States)

Andrew J. Tickle, Coventry University (United Kingdom) 
Proc. of SPIE Vol. $9116911601-6$

Downloaded From: https://www.spiedigitallibrary.org/conference-proceedings-of-spie on 26 Apr 2023 Terms of Use: https://www.spiedigitallibrary.org/terms-of-use 


\section{Introduction}

2014 saw the debut of a new emerging technologies conference dedicated to Sensors for Next Generation Robotics. We envisioned our conference as a meeting forum for engineers and scientists, from academia, industry, and national labs, focusing on emerging sensors and their applications for robotics. Since every robot is equipped with sensors, we hope to bring to the forefront unique challenges of sensor fabrication, integration, information processing, control, and usability for robotics.

Due to the proliferation of mass-produced, miniaturized sensors, it is now possible to envision massively distributed sensors being used to enhance perception, cognition, and control capabilities of next generation robots. In fact, applications where new, more intelligent robots are needed cut across all dimensional scales and industrial sectors. Examples include assisted living environments, search and rescue in disaster areas, neural surgery and prosthetics, nanomanufacturing, selfdriving vehicles, human-friendly industrial assembly and smart material handling, and so on. One exciting next generation application is endowing humanoid robots with perception comparable with those of humans, including distributed touch through robotic skin, hearing, and vision, but also super-human perception, such as the ability to see in the dark. Using off-the-shelf sensors that have not been designed specifically for robotics is fraught with additional challenges that must be mitigated by consideration of power, weight, and interconnection to the robot early on in the design process.

This conference focuses on new sensors and sensor arrays for robotics and autonomous vehicles, new form factors, and packaging schemes to help integrate robots and sensors, new applications of robots enabled by increased perception capabilities, and challenges in sensor fusion, networking, and control brought about by massive amounts of sensor data available to the robot. Technical scientific papers related to robot sensors that push beyond the state-ofthe-art in industry are solicited. New robotics applications reflecting the state of art in industry, including those with dual uses (military-defense and commercialindustrial) are also welcome.

In 2014, the conference had 14 submitted papers and 15 presentations organized in 4 sessions, including: 1) Haptics and Tactile Sensing, 2) Sensor Arrays and Interaction Control, 3) Remote Sensing and Sensor Networks, and 4) Sensor Fabrication and Evaluation. We envision that the number of papers and

attendance at our conference will increase in future years, as robots become more ubiquitous in our daily lives. We look forward to your participation in 2015!

\section{Dan O. Popa Muthu B. J. Wijesundara}


Proc. of SPIE Vol. $9116911601-8$

Downloaded From: https://www.spiedigitallibrary.org/conference-proceedings-of-spie on 26 Apr 2023 Terms of Use: https://www.spiedigitallibrary.org/terms-of-use 